\title{
THE PARADIGM SHIFT IN THE RELATIONSHIP BETWEEN THE CUSTOMER AND THE BANK IN THE NEW POST-CRISIS WORLD ECONOMY: DEMAND AND THE NATURE OF DEMAND
}

\author{
Cristian Octavian GOICEANU*
}

\begin{abstract}
Looking back on the latest financial crises, especially in 2008, it can be seen that financial markets have reacted contrary to economic theories, and even for a while have been uncontrollable. The element of stability was, contrary to current economic models, the governments of countries that were forced to intervene arbitrarily in the financial markets and save companies from bankruptcy.
\end{abstract}

Keywords: financial markets; economy; product; cultural model; customer

DOI: 53373 / REDS.2021.53.4.057

In my opinion, this means that the axiom of "markets regulate themselves" is no longer $100 \%$ true in the current global economic context in which economics is intertwined with politics, and strategic thinking for many companies is done globally. This idea is taken up by several economists, including John Komlos, who concluded that "we are going through a crisis of economic thinking so intense that a paradigm shift is needed."1

Another example is W Brian Arthur, a name with a special weight in complexity theory, who says that "Actors in economics do not face clearly defined problems and do not resort to a superhuman reality when making decisions. They explore, try to find meaning and react to the results they produce together.... Bubbles and collapses occur, markets can be gambled or exploited, and history and institutions matter. the result is a rigorous and realistic picture of the economy"

What the economists of this new current have in common is the fact that the vision of reality is different and that the real economy is totally different from the one studied in universities. This coupled with the emergence of globalization, global strategic thinking, the existence of information and the ability to access information in real time leads to the paradigm shift that John Komlos talks about in his book "The Principles of Economics in a Post World crisis".

*PhD Student, Institutul Naţional de Cercetări Economice al Academiei Române

1 John Komlos, Principiile economiei intr-o lume postcriza: Ed. Centrului de Informare şi Documentare Economică, 2019

${ }^{2}$ W. Brian Arthur, external professor , SAnta Fe Institute, http://tuvalu.santafe.edu/ wbarthur/Demand and nature of demand 
This paradigm shift has many facets, but in this article I will refer to "Demand and the nature of demand."

One of the axioms that still persists in the economy is that of the customer and the fact that he is sovereign in terms of the demand he induces in the market, and the market only has to satisfy his demand. That is, he has all the necessary information before entering the market, his desires are also formed before entering the market and the companies operating in the market have not influenced his desires in any way.

This axiom is valid only if the consumer or customer thinks logically and without emotion when establishing their needs and also has all the information they need. Consequently, the requirements it will issue represent entirely its needs, which are not influenced at all by the companies in the market. In my opinion this is not possible because product information is only found in the market and today's consumer has a perception of reality that is not just logical thinking but here we include emotions, level of education, culture, his cognitive behavioral training that defines everyone's personal reality.

Due to these reasons we can say that the consumer's desires are not exogenous or are no longer exogenous as it was considered until now but are endogenous. In his book "Principles of Economics in a Post-Crisis World," John Komlos says that "Consumer sovereignty is the dominant doctrine that consumers dictate which enterprise to produce as long as they vote with their dollars to direct production to satisfy their desires." It is assumed that tastes are formed outside the economy, they are considered to be exogenous to the economic system.

However, this model is based on the crucial but unfounded assumption that tastes are exogenous, meaning that desires are determined before the individual enters the economy. This means that corporations do not affect our desires. This is a convenient assumption, but completely wrong, because it is all too obvious that the corporate world is deeply influencing our culture and desires through advertising campaigns. That is why our tastes are endogenous to the economic system. "3

Juliet Schor ${ }^{4}$ has a similar view, arguing that media manipulation of the unconscious lays the groundwork for a culture of consumerism and cannot be countered by rational processes once the child becomes an adult.

In this context, the requirements of the person and the determination of their authenticity are more and more important (they are requirements induced by companies or they are native requirements). According to John Komlos ${ }^{5}$, consumer requests are divided into:

\footnotetext{
${ }^{3}$ John Komlos, Principiile economiei intr-o lume postcriza: Ed. Centrului de Informare si Documentare Economica, 2019

${ }^{4}$ Juliet Shor, Born to Buy: The Comercialized Child and the New Consumer Culture: New York Ed. Scribner, 2005

${ }^{5}$ John Komlos, Principiile economiei intr-o lume postcriza: Ed. Centrului de Informare si Documentare Economica, 2019
} 
- basic or basic necessities; this includes the minimum necessities for survival such as: food, water, shelter, medical clothing and the like without which we could not live;

- goods to meet comfort needs; these are the goods necessary for a dignified life in society: this category includes access to education, car, computer phone and the like without which we cannot function efficiently in the society in which we live;

- luxury goods; these are goods that do not meet basic or comfort needs and are consumed due to:

- $\quad$ an acquired skill,

- a manipulation;

- the need to reach a certain social status.

Depending on the type of product they want to promote, companies create advertisements and media clips with a message addressed to the category of consumers they target.

As the goods in the first category do not need too much marketing to promote the products, the fight is for the products in the second and third category, mainly for those in the third category. That is why consumers are being assaulted in today's world with advertisements that either influence their unconscious or create conditioning.

An example of unconscious influence is advertisements that associate a person's basic needs such as safety, minimum comfort, health with a particular product. When the manufacturing company associates a product with the basic needs of the person, in his mind the basic needs are associated with this product, which will lead, when one of these basic needs is not met, if not to buying the product at least when considering its purchase.

Another way to influence people is by creating conditioners. This way of influencing works on the Pavlovian model.

This involves associating one or more positive emotions / states with a product. In this way the person associates the emotions / states with the company's product. Thus, when the person sees the product in the store, the previous positive emotions on which the product is anchored can lead to the purchase of the product or at least to the consideration of its purchase.

In both cases, the purchase of the product is the reward that closes the loop of the customer satisfaction cycle. The only thing that matters is how moral it is to influence it.

In the Romanian banking financial system, as well as in the world one, this type of influencing the demand is often encountered.

Thus, mortgage ads are generally related to positive emotions / moods that are related to family, family safety, and that positive feeling of "being home." This type of advertising superimposed over the cultural model of the Romanian consumer who wants a personal home and corroborated with the fact that housing is one of the basic needs of the person becomes a strong influencing factor that will propel the acquisition of a real estate loan as high as possible. consumer priorities. Being a mass 
phenomenon, meaning that not only a bank has this kind of advertising but almost the entire financial system, all that remains for the person to do is to find the most advantageous financial real estate loan.

In conclusion, given that consumers are constantly exposed to a media assault on various channels (TV, social media, etc.) and that they are influenced by companies either through strategies that create conditioning or by influencing the unconscious, we can no longer consider that demand remains exogenous and the consumer is sovereign.

Consequently, we can consider the demand as endogenous and the consumer will have a limited satisfaction with the purchase of a product, considering that there is always a new product that he will be influenced to buy.

That is why we can consider that this type of consumption does not offer the person / consumer a better life but only a limited satisfaction in time. Also, the question of the morality of the whole process remains under discussion.

\section{Bibliography:}

- Gummesson, E., 2008. Total relationship marketing. 3rd Ed. Boston: Ed.Amsterdam, Heidelberg etc. Elsevier

- Han, S. şi Wilson, D.. Antecedents of Buyer Commitment to a Supplier: A Model of Structural and Social Bonding. University Park - Marketing Department

- John Komlos, 2019. Principiile economiei intr-o lume postcriză: Ed. Centrului de Informare si Documentare Economică

- Juliet Shor, Born to Buy: The Commercialized Child and the New Consumer Culture 2005: New York Ed. Scribner

- Kotler, Ph. şi Armstrong, G., 2003. Principiile Marketingului. 2nd Ed. Bucharest: Ed. Teora

- Lynch, J., 1996. Psychology of relationship banking. Cambridge: Gresham Books

- Thomas Piketty 2015. Capitalul in secolul XXI: Ed. Litera

- W. Brian Arthur, external professor, Santa Fe Institute,

- http://tuvalu.santafe.edu/ wbarthur/ 